\author{
Lidija Cvikić ${ }^{1}$, Antonia Ordulj ${ }^{2}$ \\ ${ }^{1}$ University of Zagreb, Faculty of Teacher Education, ${ }^{2}$ University of Zagreb, Faculty of \\ Humanities and Social Sciences \\ lidija.cvikic@ufzg.hr,antoniasvetic@gmail.com
}

\title{
Writer visibility in L1 vs. L2 argumentative writing: Use of the first person personal pronouns in Croatian ${ }^{1}$
}

\begin{abstract}
Developing writing encompasses acquiring linguistic features, register and style related to text type and genre, and learning to write means learning to express oneself in written form. Involvement of the author in the text, or writer visibility, is characterized by first and second person reference, the speaker's mental processes, monitoring of information flow, emphatic particles, etc. (Petch-Tyson 1998). Various studies showed that writer visibility depends on discourse type, cultural conventions, language proficiency, writer's L1, etc. (Ädel 2001; Petch-Tyson 1998; Rodríguez, Vázquez and Guzmán 2011; Zolotova 2014). This paper investigates writer visibility in Croatian L1 and L2 argumentative writing. The main research question is how Croatian L1 and L2 writers differ in the use of I-perspective compared to we-perspective, both quantitatively and qualitatively. For the purpose of this paper argumentative essays in Croatian as L1 and L2 (N=80) are analyzed for their frequencies and discourse functions. The results show that first person personal pronouns are used more frequently in Croatian L2 than in L1 writing. However, only the overuse of $I$-form is proven to be statistically significant. The qualitative analysis shows that in Croatian L1 and L2 writing, the pronoun $I$ is most frequently used to express discourse functions of writer's stance and writer's experience, whereas the pronoun we is used for the same purpose (presenting a general claim), thus to a much lower frequency. Besides similarities of L1 and L2 writing, the study shows the tendency of non-native speakers to use certain discourse function more frequently. The obtained results gave more insight into writing in Croatian, and confirm cultural, linguistic, and language learning influences to writing in both L1 and L2.
\end{abstract}

1 This work has been supported by the Croatian Science Foundation under the project 1P-2016-06- 5736: Textual Coherence in Foreign Language Writing (KohPiTekst). 


\section{Introduction}

Writing is considered to be the most complex language skill involving psychomotor, cognitive and linguistic activity (Bazerman 2009; Byrnes and Manchon 2014). While spoken language is determined by the situation and the presence of the audience or at least an interlocutor, writing is a more abstract process that requires a clear and unambiguous expression of thoughts. Grabe and Kaplan (1996: 6) claim that "writing is not a natural ability that automatically accompanies maturation", but it is "a technology, a set of skills which must be practiced and learned through experience". Therefore, writing must be instructed and practiced in both first (L1) and second/foreign language learning (L2) (Ball and Ellis 2009; Wang 2012; Wells Rowe 2009). Manchón (2011) argues that in the context of L2, writing could be explored in two dimensions: learning-to-write and writing-to-learn. According to Manchón (2011:3) L2 users learn how to express themselves in written (learning-to-write), while at the same time they use the written activities to practice language and/or to expand their content knowledge (writing-to-learn). Undoubtedly, the same distinction could also be applied to learning of writing in L1. Manchón (2011) identifies two main theoretical frameworks that are steering research of learning-to-write: the psycholinguistic-cognitive, and the sociocultural perspective (e.g. Dyson 2000; Gee 2003; Whitmore, Martens, Goodman and Owocki 2004). Besides the structure and linguistic features of a particular language, writing is influenced by many cultural and individual factors such as motivation and purpose for writing. While providing the opportunity to investigate universal cognitive and linguistic processes (Bestgen and Granger 2014; Michel et al 2019) research on writing explores language specific, cultural-bound and individual features of writing (Keller et al 2020; Kubota and Lehner 2004) at the same time. Writer/reader visibility, the ability of writers to present their personal feelings and attitudes, and address the reader in a text (Petch-Tyson 1998: 111) can be considered one of the individual features of writing, i.e. of a particular text. The notion of writer/reader visibility can be achieved by the use of various linguistic features such as personal pronouns, possessives, emphatic particles, monitoring of information flow, etc. (Petch-Tyson 1998: 111). In other words, individual features of writing (e.g. writer/reader visibility) can be achieved by language-specific features.

This study explores how the notion of writer visibility is expressed by linguistic features of the Croatian language. More precisely, it explores the use of first person personal pronouns as a means of expressing writer/reader visibility by Croatian native and non-native speakers/writers. In the following sections, the notion of writer/reader (W/R) visibility is introduced, followed by the review of relevant literature. In the second part of the paper, research questions, data and methodology of the present study are described in detail, followed by the interpretation of findings on writer/reader (W/R) visibility among Croatian native and non-native writers. 


\section{Theoretical background}

In this section, we discuss the concept of writer/reader visibility as a pragmatic feature of a discourse, expressed by means of the first person personal pronouns in native and non-native writing context.

\subsection{Writer/reader visibility in L1 and L2}

The representation of writer in a text is commonly referred to as discoursal identity (Ivanic 1998), authorial identity (Hyland 2002) or writer/reader visibility (Zolotova 2014). Different studies examined W/R visibility from various perspectives: native vs. non-native (Bikelienè 2016; Paquot, Hasselgård and Ebeling 2013; Rodríguez, Vázquez and Guzmán 2011; Zolotova 2014), academic genre vs. argumentative genre (Bikelienè 2016; Rodríguez, Vázquez and Guzmán 2011; Zolotova 2014), language proficiency (Bikelienè 2016; Breeze 2007; Chang 2015), cultural differences (Ädel 2001; Luan and Zhang 2016; Paquot, Hasselgård and Ebeling 2013) etc. Hyland (2002) argues that the expression of W/R identity is determined by the culture of a (professional) community to which the text belongs, and the home culture of the author. For that reason, the notion of (non)-nativeness plays an important role in addressing the issue of writer/reader visibility. Zolotova (2014: 21) points out the importance of nativeness, claiming that even in cases where second language learners produce texts that are fully grammatical, such texts "would be a 'foreignism' to a native speaker" due to their lexical and rhetorical features. Specifically, native speakers use idiomatic expressions, syntactic and lexical bundles "with a definite frequency in a certain context" (Zolotova 2014: 21) and a native-like text should "construct author's identity according to certain rhetoric rules" (ibid.). If the rhetoric rules are not obeyed in the text, the text can be misunderstood by its readers. Nevertheless, nativeness is not the only isolated factor that influences the expression of W/R visibility in a text. The study on W/R visibility in English texts written by non-native (Lithuanian) and native (English) university students (Bikelienè 2016) took into consideration genre, language proficiency, institutional, and L1 variables. The results suggested that W/R visibility is in close relation with language proficiency, i.e. "the more proficient the learners are, the more likely they are to be overtly present in their writing" (Bikeliene 2016: 39). However, different authors' preferences were observed regarding text genres. In argumentative essays and research papers native speakers (NS) and nonnative speakers (NNS) showed similar use of W/R visibility markers, whereas in proposals NNS were trying to avoid the usage of writer visibility features (ibid.). Another study on the use of W/R visibility features across genres was conducted by Paquot, Hasselgarrd and Ebeling (2013). The goal of the study was to compare argumentative texts with discipline-specific texts between NNS (French and Norwegian English language learners) and English NS writing, using different corpora. The main results suggested that $W / R$ visibility markers are less common in academic or disci- 
pline-oriented student texts than in argumentative essays. At the same time, they were overused by all NNS, regardless of their L1, in all types of text (Paquot, Hasselgård and Ebeling 2013). This is in line with the findings by Hyland (2002), who analyzed W/R visibility in L2 student academic writing from eight scientific fields in comparison to published articles from the same fields. The study confirmed nativeness and discipline influence, i.e. "the professional writers were four times more likely to explicitly intervene with the first person, with figures higher for the soft disciplines than the hard ones" (Hyland 2002: 1098).

The presented studies provide evidence that a combination of several factors, such as text genre, nativeness, and the level of L2 language proficiency, contributes to W/R visibility in a text. Hyland (2002) explains the significance of these three factors. First, novice writers and professionals differ considerably "in their knowledge and understanding of appropriate academic conventions and practices" (Hyland 2002:1096), since the acquisition of disciplinary knowledge is at the same time the acquisition of a new type of literacy. Second, the authorial self is more explicit in soft disciplines, because "the criteria of acceptability for interpretation are less clear-cut and variables less precisely measurable than in the hard fields" (Hyland 2002: 1098). Third, L2 writers are to be given special support in mastering self-reference in academic texts because "the absence of clear direction in their pedagogic texts, the positioning of institutionally authoritative discourses, and the preferred cultural practices for authorial concealment, mean that self-mention can be a considerable problem for L2 undergraduate writers" (Hyland 2002: 1095).

Rodríguez, Vázquez and Guzmán (2011: 112) showed that "straight assertions, strong arguments, and stylistic choices also contribute to achieving authoritativeness in writing". However, Hyland (2002: 1093) claims that "one of the most obvious and important ways writers can represent themselves to readers however is to explicitly affirm their role in the discourse through first person pronouns".

\subsubsection{Use of first person personal pronouns for expressing $W / R$ visibility in L1 and L2}

The ability of a writer to represent and express themselves in a text can be expressed by various linguistic and/or rhetorical features, but "most visibly in the use of first person pronouns and possessive determiners" (Hyland 2002: 1092). In her study, Vassileva (1998) uses the term "the I and the we perspective" emphasizing that different writer perspectives are visible not only in the personal pronouns, but in the possessives (me, mine vs. our, ours) as well. In general, the personal pronoun I usually refers to the writer's personal stance, viewpoints, opinions, personal experiences and beliefs (Petch-Tyson 1998; Zolotova 2014) or it is used to indicate the structure of the text (Zolotova 2014). In contrast to the pronoun I, which points out (only) the author's position, the pronoun we brings other perspectives into the text. The personal pronoun we might be used to establish the connection between 
the author and the reader through shared viewpoints, opinions, experiences or beliefs (Luan and Zhang 2016). The relationship between the author and "the others" established by the pronoun we can be two-fold: inclusive and exclusive (Fløttum et al 2006; Harwood 2005; Hyland 2002; Zolotova 2014). The inclusive we refers to the first and second person singular form (I + you), while the exclusive we refers only to the first person singular form and third person singular/plural form (I + he/ she/they) (Marković 2012). By using we, the author can sometimes present a general claim or value of the whole society (Chang 2015; Luan and Zhang 2016), which is often referred to as a generic we (Zolotova 2014).

Several studies examined the use of personal pronouns as markers of W/R visibility by NS and NNS in various text genres. The W/R presence in essays and reports of Spanish students of English L2 was examined by Breeze (2007). The results confirmed a general lack of awareness of genre differences, i.e., in the essays the most frequent personal pronoun was $I$, used to express personal opinions. On the other hand, reports were "perceived as a type of collective task involving others" (Breeze 2007: 20), which can be observed through more frequent usage of we, than in the essays. In the study by Bikeliene (2016) the participants showed equal use of singular person markers in argumentative essays and research papers. In contrast, in order to show explicit writer presence in the text of proposals, NNS were using mostly plural markers. The results confirmed "significantly higher authorial presence in NNS writing" (Bikelienè 2016: 39) than in NS texts by more frequent usage of plural markers.

Several studies have confirmed cultural and linguistic influences on the use of personal pronouns to express W/R visibility. McCrostie's (2008) analysis of argumentative essays written by Japanese learners of English showed very frequent use of the pronoun I to express personal opinion, in contrast with native English speakers. The same results were confirmed in the same type of writing by Taiwanese students of English L2 at three different proficiency levels (Chang 2015). In general, the most frequently used pronoun was I, followed by we and you (Chang 2015). However, there were considerable differences in the use of personal pronouns regarding the students' proficiency level in English.

First and second person personal pronouns and epistemic modal verbs were the most frequent W/R visibility features used by Norwegian EFL learners, and one possible explanation is that "Scandinavian writers favor a less formal, more interactive writing style" (Paquot, Hasselgård and Ebeling 2013: 8). Cultural differences in the use of personal pronouns among NS of British and American English writers, and Swedish advanced learners of English are also reported by Ädel (2001). While British English writers are more focused on the use of we, stressing shared personal experience, Swedish and American English writers are more overtly present in the argumentative essays by using I (Ädel 2001: 8). Similar results for Swedish learners of English are confirmed by Luan and Zhang (2016), who showed the overuse of I by Swedish learners, which can be explained by their "stronger sense of self-iden- 
tity inherited from their traditional culture or value" (Luan and Zhang 2016: 350). The authors also suggested that Chinese students like to be modest and "consider things as a member of a group" (Luan and Zhang 2016: 350), and therefore the overuse of we in their essays is not surprising. Apart from traditional cultures and values, the differences between Swedish vs. Chineselearners' writing in English can be driven by teaching methods. While Chinese teachers do not encourage students to express their own opinions, leaving students to follow lectures more passively, Swedish teachers are trying to foster students' creativity to express their own ideas freely (Luan and Zhang 2016: 350). This finding is in line with Hyland's (2002) observation that a cause of the uncertainties of writers to express themselves in L2 lies in the textbooks for teaching writing. While many textbooks give advice to the students to avoid usage of personal statements, other encourage them to clearly express their opinion and voice (Hyland 2002: 1095).

A thought-provoking and important study on author identity in English L2 writing by learners with Slavic L1 background was conducted by Zolotova (2014). The study showed that Russian learners of English overuse all personal pronouns. However, comparing to other Slavic L1 users of English, the study confirmed some features of the use of English personal pronouns to be typical for Russian learners only. More precisely, in argumentative essays Russian learners of English overuse the pronoun we more than the pronoun I.Zolotova (2014:135) argues this to be the result of L1 transfer, since the frequencies of Russian L1 grammatical units, their function, register and form are mirrored in the English L2 writings. The overuse of personal pronouns is also confirmed in academic writing, but at a much smaller rate (Zolotova 2014). Zolotova (2014: 135) concludes that in academic writing Russian learners of English benefit from their academic experience and "distribute the use of the 'I' and the 'we' perspectives in more nativelike way". Zolotova (2014) also investigated the effect of different Slavic L1 to English L2 writing and the results proved the effect of the language. More precisely, in argumentative essays "the first person pronouns are least frequent in Polish L2 writing, and are most frequent in Czech and Bulgarian writing" (Zolotova 2014: 130), whereas Russian L2 writing is somewhere in the middle. When it comes to academic writing, "Czech learners overuse the I-perspective stronger than other learners' varieties" (Zolotova 2014: 132). Together with the afore mentioned findings by Paquot, Hasselgård and Ebeling (2013) and Ädel (2001), Zolotova's (2014) study provides more support for the hypothesis that the use of first-person personal pronouns in expressing W/R visibility is not only cultural, but language determined as well.

The evidence presented in this section showed opposite tendencies in expressing $\mathrm{W} / \mathrm{R}$ visibility by native and non-native speakers/writers. While NNS overuse the I-perspective to overtly show author's presence, NS do not. The differences in use of W/R visibility features are observed with respect to proficiency levels. Learners at advanced levels do not use personal pronouns in the same way as their counterparts at intermediate or lower proficiency levels. Writer/reader visibility is also 
characterized by cultural differences in the use of personal pronouns among NS and NNS. Finally, the use of first-person personal pronouns to express W/R visibility depends on the learner's L1, which can be explained by cultural differences on one hand and as a result of L1 transfer or academic experience on the other hand.

As indicated previously, most studies on W/R visibility have dealt with English, either as L1 or L2, whereas the same topic is less widely investigated in other languages. For example, Didriksen and Gjesdal (2006) investigated the usage of personal pronouns in French L1, Tayyebi (2012) in Persian, Vassileva (1998) in German, French, Russian and Bulgarian L1, and Zolotova (2014) in Russian L1. Based on our knowledge, there is a general lack of research on W/R visibility in a Slavic language as L1 and L2. This study aims to fill that gap.

\section{Study}

\subsection{Aim and methods}

\subsubsection{Aim of the study}

The main aim of this study is to give more insight into the use of I- and we-perspective as a means of expressing W/R visibility in Croatian NS and NNS argumentative essays. The study was conducted to address the following research questions:

1. Do Croatian L1 and L2 writers differ in the frequency of use of first person personal pronouns in argumentative essays?

2. Do Croatian L1 and L2 writers differ in the use of various discourse functions of first person personal pronouns in argumentative essays?

\subsubsection{Methods}

In order to explore the use of personal pronouns in argumentative essays of Croatian NS and NNS, we investigated a corpus of argumentative essays created for the purpose of the research project "Textual coherence in foreign language writing: Croatian, German, English, French and Hungarian in comparison (IP-2016-065736). The corpus consists of essays written by native and non-native speakers (language learners) of all five investigated languages. All essays in the corpus are written on the same topic (Life in the city) and comprise 200-250 words, which ensured comparable quantitative (size) and qualitative (lexical and grammatical features) characteristics of all sub-corpora.

For the purpose of this study 80 essays written by two groups of authors were analyzed. The first group of participants, i.e., essay authors, consisted of 40 students of foreign languages at 3 Croatian universities, all native speakers of Croatian (NS). The second group of participants consisted of 40 learners of Croatian as L2 (NNS) at the B1 level from the University of Zagreb. It should be emphasized that the sample structure of NNSs was heterogeneous regarding the first language (L1 
German=14, L1 English=20, L1 French=6), since it was not possible to collect the same number of essays for each L1 by the authors who have the same level of acquisition of the Croatian language. All participants signed an informed consent form.

The participants were given a short instruction for writing (Some people claim that life in the city has many advantages. Other think exactly the opposite. Write a composition with the title 'Life in the city' in which you present both points of view, express your opinion and give supporting arguments.) in the language in which the essay was supposed to be written.

Since the essays were hand-written, they were transcribed into an electronic form and prepared for the analysis. The essays of NNS were not corrected for grammatical or spelling errors. Each essay was coded for participant ID and his/her L1. All investigated essays $(\mathrm{N}=80)$ were also coded for the discourse functions of personal pronouns in Nvivo 11 for Mac, and qualitative analysis of the type and frequency of discourse functions was conducted. The collected data was quantitatively analyzed for non-parametric statistics using SPSS.

\section{Results}

\subsection{Use of first person personal pronouns}

The investigated corpus consists of 18159 tokens (9888 tokens in NS writings and 8271 tokens in NNS writings). The average length of NS essays was 247 tokens, and of NNS essays 207 tokens.

The overall frequency of the use of the nominative form for the first person singular personal pronoun I (Cro. ja) and the first person plural personal pronoun we (Cro. mi) by both groups of writers is shown in Table 1.

\begin{tabular}{|l|c|c|c|}
\hline & $\begin{array}{c}\text { Pronoun I in } \\
\text { Nominative case } \\
(f)\end{array}$ & $\begin{array}{c}\text { Pronoun we in } \\
\text { Nominative case } \\
(f)\end{array}$ & $\begin{array}{c}\text { Total } \\
(f)\end{array}$ \\
\hline Croatian native speakers & 9 & 1 & 10 \\
\hline Croatian non-native speakers & 44 & 7 & 51 \\
\hline total & 53 & $\mathbf{8}$ & \\
\hline
\end{tabular}

Table 1. Usage of 1 st person personal pronouns in nominative case by Croatian native and non-native speakers 
The results in Table 1 show two tendencies. First, the use of the pronoun $I$ $(\mathrm{f}=53)$ is considerably higher than the use of the pronoun we $(\mathrm{f}=8)$. Second, nonnative speakers tend to use the investigated personal pronouns more often $(\mathrm{f}=51)$ than native speakers $(\mathrm{f}=10)$.

Table 1 shows the results of the use of the personal pronouns I and we in the nominative case. The writer's viewpoint can be expressed as the viewpoint of the subject of the sentence, which is expressed in the nominative case. However, other inflectional forms of the same pronouns can be used to express W/R visibility, for example the dative form (1) or the accusative form (2).
(1) čini mi se seem-3sg.PRES I-D sg. myself 'it seems to me'
(2) za mene je for I-ACC.sg. be-3sg.PRES 'it is for me'

Therefore, the data was analyzed for the frequency of all inflectional forms of the first person personal pronouns (Table 2).

\begin{tabular}{|l|c|c|c|}
\hline & $\begin{array}{c}\text { total I forms } \\
(\mathrm{f})\end{array}$ & $\begin{array}{c}\text { total we forms } \\
(\mathrm{f})\end{array}$ & $\begin{array}{c}\text { Total } \\
(\mathrm{f})\end{array}$ \\
\hline & & & \\
\hline Croatian native speakers & 34 & 9 & 43 \\
\hline Croatian non-native speakers & 84 & 20 & 104 \\
\hline total & $\mathbf{1 1 8}$ & $\mathbf{2 9}$ & \\
\hline
\end{tabular}

Table 2. The frequency of all inflectional $I$ and we forms

Table 2 presents the breakdown of the frequency of all inflectional forms of the I and the we pronoun used by native vs. non-native Croatian speakers. As shown in the Table 2, NNS use the forms of both personal pronouns over twice as frequently $(\mathrm{f}=104)$ than NS $(\mathrm{f}=43)$. As already confirmed for the nominative case, the use of $I$ forms is four times more frequent $(\mathrm{f}=118)$ than the usage of we forms $(\mathrm{f}=29)$. Figure 1 shows the breakdown of the data in Table 2 by nominative vs. other cases. 


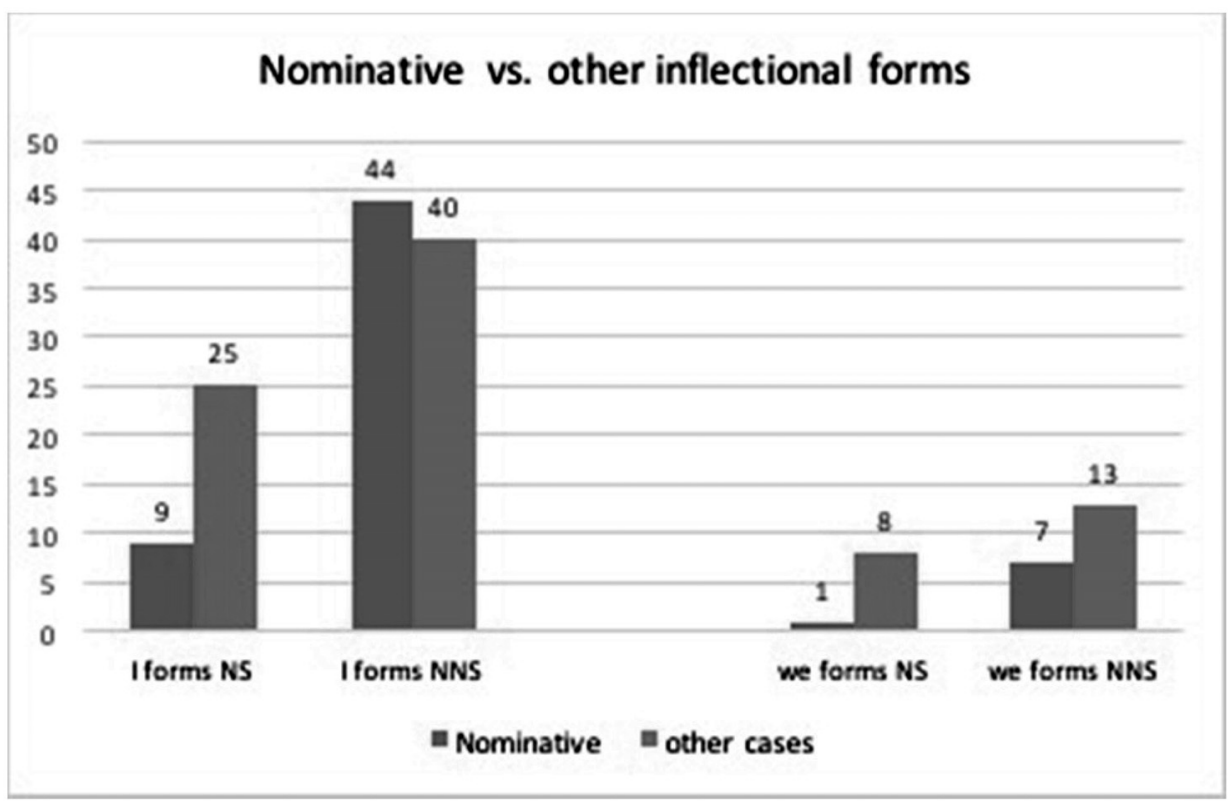

Figure 1. Nominative vs. other inflectional forms of $I$ and we pronoun used by native and non-native speakers.

Figure 1 illustrates the distinct use of $I$ forms by NS vs. NNS. The results reveal that NS use I more frequently in other inflectional forms $(\mathrm{f}=25)$ that in the nominative case $(f=9)$. However, NNS use nominative and other cases equally frequently, although slightly more often in the nominative $(\mathrm{f}=44)$ than in other cases $(\mathrm{f}=40)$. Surprisingly, the tendency of the use of the pronoun we is the same for both groups of speakers/writers, i.e. inflectional forms of we are used more often (NS $\mathrm{f}=8$, NNS $\mathrm{f}=13$ ) than nominative form ( $\mathrm{NS} \mathrm{f}=1$, NNS $\mathrm{f}=7$ ).

The obtained results show that NNS use both investigated personal pronouns (I and we) more frequently than NS. Both groups use I forms more frequently than we forms. However, the two groups differ in the use of nominative vs. other inflectional forms of the pronoun I. NS use nominative I form less frequently than other inflectional forms, while NNS use nominative I forms slightly more frequently than other inflectional forms.

In order to investigate the extent to which the two groups differ in the use of personal pronouns, a non-parametric statistical analysis was conducted (MannWhitney test). The results (see Table 3 ) show that there is a significant difference $(p<0.001)$ between NS and NNS in the use of the pronoun I in the nominative case $(\mathrm{p}=.002)$ and in all other cases $(\mathrm{p}=.002)$. The two groups of writers do not differ statistically to a significant degree in the use of we pronoun neither in nominative nor in the other cases. In summary, the results confirm that compared to native speakers, non-native speakers of Croatian overuse the personal pronoun I in argumentative writing. 


\begin{tabular}{|l|l|l|l|l|l|l|}
\hline & $\begin{array}{c}\text { speaker/ } \\
\text { writer }\end{array}$ & $\mathrm{N}$ & Mean Rank & $\begin{array}{c}\text { Sum of } \\
\text { Ranks }\end{array}$ & $\begin{array}{c}\text { Mann- } \\
\text { Whitney-U }\end{array}$ & $\begin{array}{c}\text { Asimp. } \\
\text { Sig. (2- } \\
\text { tailed) }\end{array}$ \\
\hline I- Nom case & Native & 40 & 33.69 & 1347.50 & & \\
\hline & Non-native & 40 & 47.31 & 1892.50 & & \\
\hline & Total & 80 & & & 527.50 & .002 \\
\hline & Native & 40 & 38.48 & 1539.00 & & \\
\hline we- Nom \\
case & Non-native & 40 & 42.53 & 1701.00 & & \\
\hline & Total & 80 & & & 719.00 & .088 \\
\hline & & & & & & \\
\hline & Native & 40 & 32.91 & 1316.50 & & \\
\hline I-all cases & Non-native & 40 & 48.09 & 1923.50 & & \\
\hline & Total & 80 & & & 496.500 & .002 \\
\hline & & & & & & \\
\hline & Native & 40 & 38.00 & 1520.00 & & \\
\hline we-all cases & Non-native & 40 & 43.00 & 1720.00 & & \\
\hline & Total & 80 & 00 & & 700.00 & .177 \\
\hline & & & & & & \\
\hline
\end{tabular}

Table 3. Non-parametric statistical analysis of the usage of the pronoun I and the pronoun we

\subsection{Discourse functions of first person personal pronouns}

The results reported in the previous section confirmed quantitative differences in the use of first person personal pronouns in Croatian L1 and L2 argumentative essays. Nevertheless, in order to explore the difference in expression of W/R visibility in Croatian L1 and L2 in more depth, a qualitative analysis was performed. All occurrences of the first person personal pronouns were coded by their function. For that purpose, the classification by Bagaric Medve and Saric Sokcevic (2018) was applied. Bagaric Medve and Saric Sokcevic (2018) based their classification on Hyland (2002) and Chang (2015), introducing a novel function of the you form - representing the writer's subjectivity or knowledge superiority over the reader. The classification by Bagaric Medve and Saric Sokcevic (2018) was selected because it was designed to analyze the writing from the same corpus used in this study, but for different languages (English and German L2 text written by Croatian L1 writers). It was assumed that the classification will be more in line with the cultural and language specificities of the corpus, and the results will be more comparable. The list of the 
discourse functions of the first person personal pronouns (Bagaric Medve and Saric Sokcevic 2018) is presented in Table 4.

\begin{tabular}{|l|l|}
\hline Discourse function of pronoun I & Discourse function of pronoun we \\
\hline $\begin{array}{l}\text { 1. stating claims - function representing } \\
\text { writer's knowledge }\end{array}$ & $\begin{array}{l}\text { 1. establishing solidarity - promoting } \\
\text { solidarity by arousing the reader's sym- } \\
\text { pathy, understanding, thinking, etc. }\end{array}$ \\
\hline $\begin{array}{l}\text { 2. elaborating an argument - explanation } \\
\text { of writer's argumentation }\end{array}$ & $\begin{array}{l}\text { 2. toning down directives - by using the } \\
\text { cluster „we + obligation verb” }\end{array}$ \\
\hline $\begin{array}{l}\text { 3. asserting writer's stance - expressing } \\
\text { writer's view, stance or attitudes }\end{array}$ & $\begin{array}{l}\text { 3. presenting a general claim - claiming } \\
\text { the common ground and shared social } \\
\text { values, beliefs, experiences, knowledge, } \\
\text { and traditions }\end{array}$ \\
\hline $\begin{array}{l}\text { 4. a) referring to writer's experience - de- } \\
\text { scribing the writer's personal experience } \\
\text { b) referring to writer's expectation - de- } \\
\text { scribing writer's personal state of mind, } \\
\text { expectation, whishes... }\end{array}$ & $\begin{array}{l}\text { 4.indicating discourse structure - overt } \\
\text { structure marker }\end{array}$ \\
\hline $\begin{array}{l}\text { 5.indicating discourse structure - overt } \\
\text { structure marker }\end{array}$ & \\
\hline
\end{tabular}

Table 4. Discourse functions of the first person personal pronouns $I$ and we (Bagaric Medve and Saric Sokcevic 2018)

The results of the use of different discourse functions of the pronoun I in Croatian L1 and L2 writing is presented in Table 5.

\begin{tabular}{|l|c|c|}
\hline \multicolumn{1}{|c|}{ Discourse function of pronoun I } & $\begin{array}{c}\text { Croatian L1 } \\
\text { writing/NS } \\
\text { (f) }\end{array}$ & $\begin{array}{c}\text { Croatian L2 writing / } \\
\text { NNS } \\
\text { (f) }\end{array}$ \\
\hline 1. stating claims & 1 & 9 \\
\hline 2. elaborating an argument & 0 & 4 \\
\hline 3. asserting writer's stance & 19 & 24 \\
\hline 4. a) referring to writer's experience & 9 & 3 \\
\hline 4. b) referring to writer's expectation & 4 & 3 \\
\hline 5.indicating discourse structure & 1 & 41 \\
\hline
\end{tabular}

Table 5. Discourse functions of the pronoun I in Croatian L1 and L2 writing 
In general, NNS used all discourse functions more frequently than NS. The only function that was used more frequently by NS is referring to writer's expectation, but the difference in frequency was limited to only one occurrence. The considerably higher frequency of discourse functions in the writings by NNS was expected since NNS have produced considerably more personal pronouns in general (see Figure 1). In the analyzed argumentative essays NS used the pronoun I in all of its discourse functions, except for elaborating an argument, whereas NNS used the pronoun $I$ in all of its discourse functions.

The most frequently used discourse function of the pronoun $I$ by both groups of speakers is the expression of writer's stance ( $\mathrm{NS} \mathrm{f}=19$, NNS $\mathrm{f}=41$ ), whereas the second most frequently used function is referring to the writer's experience (NS $f=9$, NNS $\mathrm{f}=24$ ). In the present study, the author's stance is most commonly expressed by I think (Cro. ja mislim, ja smatram) and I like (Cro. ja volim), with the overall high frequency of the phrase it seems to me (Cro. čini mi se). The second most frequent discourse function (the writer's experience) is expressed mostly with Ilive(d) or I used to. The collected data suggest the need for reconsideration of the function referring to the writer's experience. Even though most examples refer to a specific event in the writer's life (3), some of them refer to the experience that is the result of various specific events in the writer's life (4a, $4 b)$.

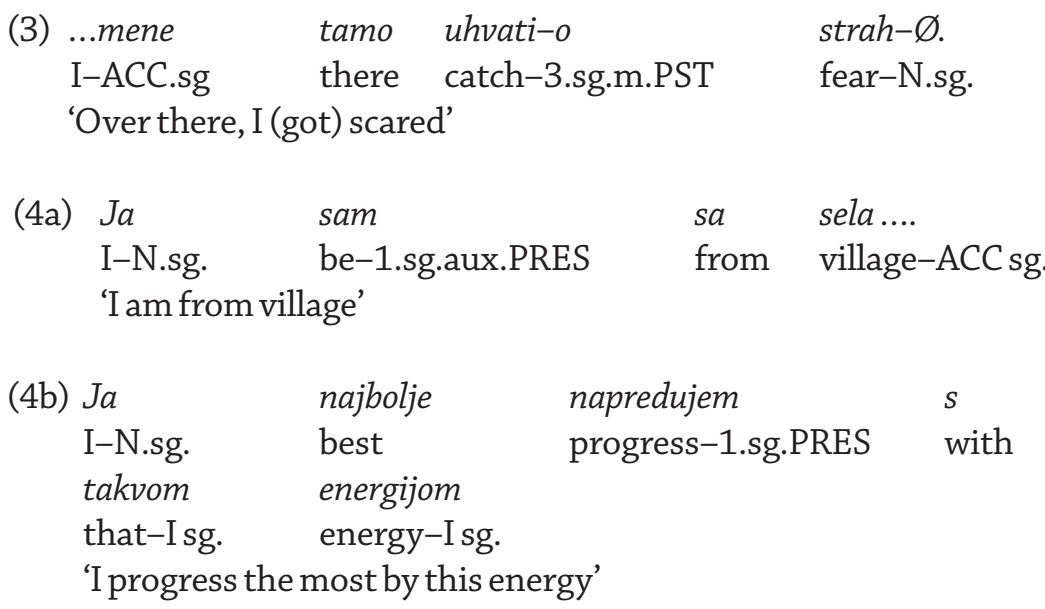

The results also show that NNS used the pronoun I to state the claim considerably more frequently than the NS, i.e., there were 9 occurrences of this function in the writings of NNS and only 1 in the writings of NS. Stating claims is the third most frequently used discourse function of the pronoun in Croatian L2 writing, whereas it is one of two least used discourse functions in Croatian L1 writing. It is the function used to present the writer's knowledge, mostly expressed with I know (5) by NS, except for only one occurrence of the verb used by NNS. 
I for

primjer- $\varnothing$

zna-m

samo

život- $\varnothing$

example-ACC.sg

know-1sg.PRES

only

life-ACC.sg. in city-LOC.sg.

'I know, for example, only the life in the city.'

The most unexpected result is that NNS use the function elaborating an argument (6), (6a), which was not found in the writing of NS.

(6) $U{ }^{*}$ mom $\quad$ *perspektiv-u, ja misli-m... In my-LOC.sg.m perspective-LOC.sg I-N.sg. think-1sg.PRES 'In my perspective, I think...'

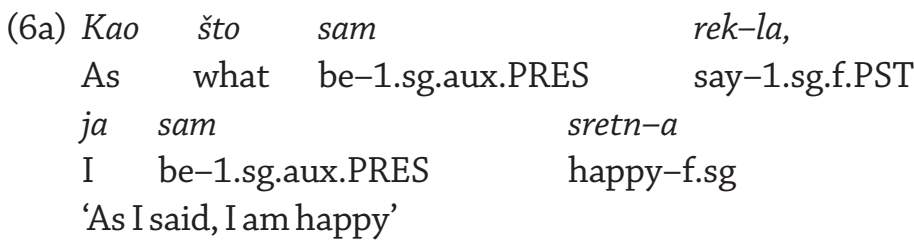

In general, the results show that NS and NNS used the same discourse functions of the pronoun I, but not to the same extent (see Table 6). Table 6 lists the use of discourse functions of the pronoun I by NS and NNS from the most frequent to the least frequent. The most noticeable difference was found in the use of the function referring to writer's expectation, which is highly used by NS and one of the least frequently used discourse functions by NNS, even though their absolute frequencies were almost the same.

\begin{tabular}{|l|l|}
\hline \multicolumn{2}{|l|}{ I pronoun discourse functions usage frequency } \\
\hline Croatian L1 writing/NS & Croatian L2 writing $/ \mathrm{NNS}$ \\
\hline asserting writer's stance $(\mathrm{f}=19)$ & asserting writer's stance $(\mathrm{f}=41)$ \\
\hline referring to writer's experience $(\mathrm{f}=9)$ & referring to writer's experience $(\mathrm{f}=24)$ \\
\hline referring to writer's expectation $(\mathrm{f}=4)$ & stating claims $(\mathrm{f}=9)$ \\
\hline stating claims $(\mathrm{f}=1)$ & elaborating an argument $(\mathrm{f}=4)$ \\
\hline indicating discourse structure $(\mathrm{f}=1)$ & referring to writer's expectation $(\mathrm{f}=3)$ \\
\hline elaborating an argument (not found) & indicating discourse structure $(\mathrm{f}=3)$ \\
\hline
\end{tabular}

Table 6. Usage of discourse functions of pronoun I by NS and NNS according to frequency 
Table 7 shows the results of the analysis of discourse functions of the pronoun we in Croatian L1 and L2 writing. In general, NNS used all discourse functions of the pronoun we more frequently than NS. The result was expected considering the fact that NNS produced more occurrences of the personal pronoun we than the native speakers (see Figure 1). Both NS and NNS used the pronoun we most frequently in two discourse functions - presenting a general claim and establishing solidarity.

\begin{tabular}{|l|c|c|}
\hline Discourse function of pronoun we & $\begin{array}{c}\text { Croatian L1 } \\
\text { writing/NS } \\
\text { (f) }\end{array}$ & $\begin{array}{c}\text { Croatian L2 writing / } \\
\text { NNS } \\
(\mathrm{f})\end{array}$ \\
\hline 1. establishing solidarity & 3 & 8 \\
\hline 2. toning down directives & 0 & 1 \\
\hline 3. presenting a general claim & 6 & 11 \\
\hline 4.indicating discourse structure & 0 & 0 \\
\hline
\end{tabular}

Table 7. Discourse functions of the pronoun we in Croatian L1 and L2 writing

Both groups of speakers/writers use the pronoun we most frequently to express the function of presenting a general claim ( $\mathrm{NS} f=6, \mathrm{NNS} f=11$ ). The function was used to express shared experience (7), knowledge (8), values or beliefs.

(7) Brojn-a dogadanj-a, koncert-i i predstav-e numerous-N.pl. event-N.pl concert-N.pl and performance-N.pl omoguću-ju nam allow-3.pl.PRES we-D

'Numerous events, concerts and performances allow us constant entertainment.'

(8) Kemikalij-e iz nuklearn-ih elektran-a Chemicals-N.pl. from nuclear-G.pl. power plant-G.pl. kvar-e nam vod-u. spoil-3.pl.PRES we-D water-A.sg. 'Chemicals from nuclear power plants pollute our water'

Zolotova (2014) and Hyland (2002) emphasize that the personal pronoun we can be used to make the text less personal and more objective, i.e., to minimize the presence of the author and "to present an argument on behalf of all people" (Zolotova 2014: 104). This tendency might be illustrated by the fact that one of the analyzed NNS essays was entirely written in the first person plural form. 
The second most frequently used function was the discourse function establishing solidarity. The function shows the writer's intention to arouse a reader's understanding, sympathy or thinking (9), or to draw its attention to the situations they are facing (10) (Bagaric Medve and Saric Sokcevic 2018).

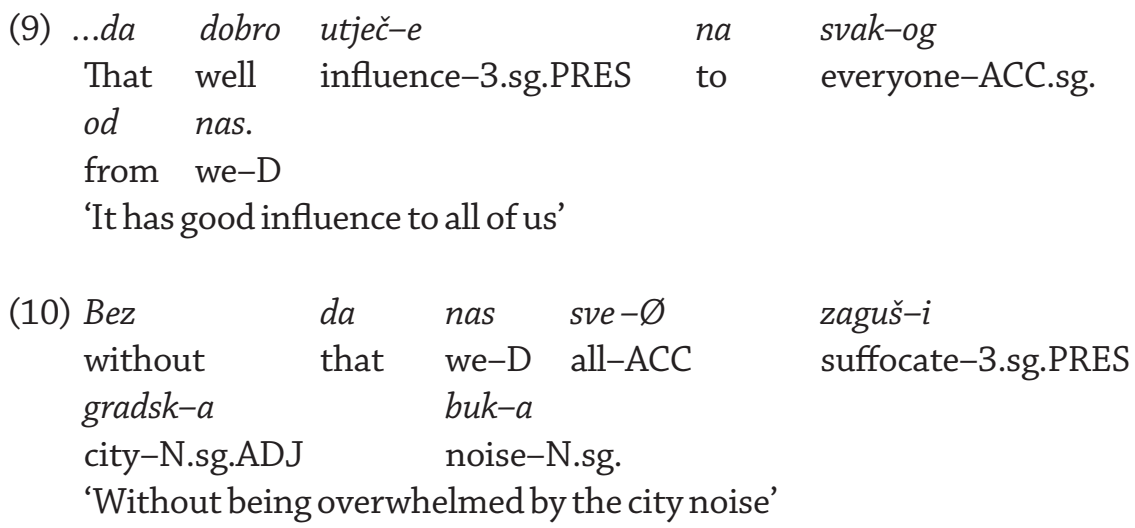

This function also includes the so called inclusive we and exclusive we (Fossen 2014; Zolotova 2014). The experience from the previous studies shows, that it could be difficult to differentiate between generic, inclusive and exclusive we (Fossen 2014; Zolotova 2014). In most of the examples we is used in a generic form (Zolotova 2014) presenting a general claim or value of the whole society (Chang 2015; Luan and Zhang 2016), as is (11). In only a few examples from the analyzed corpus a clear distinction between inclusive and exclusive we can be made. For example, in (12) exclusive we can be understood as such, only by the context (describing an episode of a writer's life with another person, i.e., a boyfriend). Rather low frequencies of we-forms, as well as the difficulties to clearly differentiate between various types of we suggest that the classification by Bagaric Medve and Saric Sokcevic (2018), with no distinction between generic, inclusive and exclusive we, is appropriate for the data analyzed.

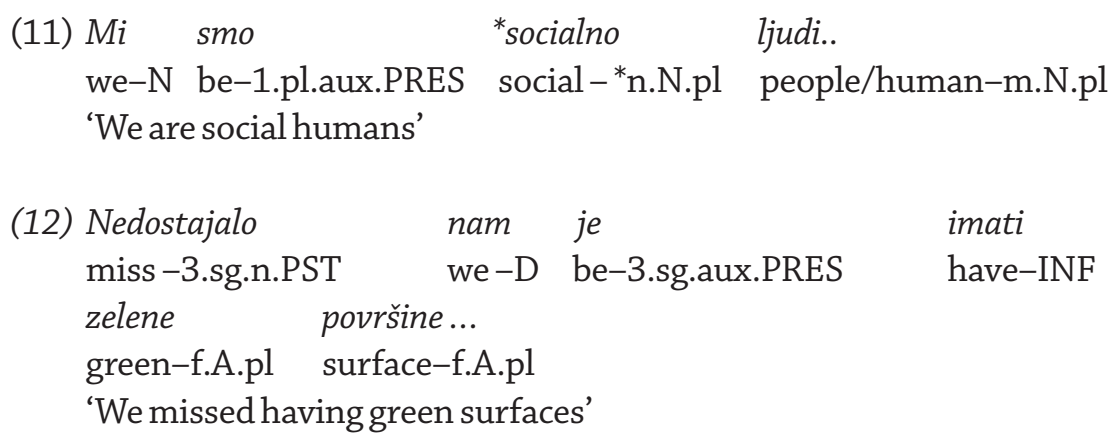


The study showed that NNS speakers used the pronoun we in all its discourse functions, with the exception of indicating discourse structure. The discourse function toning down directives is recognized by the presence of the so-called obligation verbs (Bagaric Medve and Saric Sokcevic 2018) and it occurred only once in Croatian L2 writing. Interestingly, the analyzed corpus contains an example of "chaining of sentence initial features of W/R visibility" (Petch-Tyson 1998: 114), i.e. co-occurrence of two or more markers of $\mathrm{W} / \mathrm{R}$ visibility in the beginning of the sentence (13).

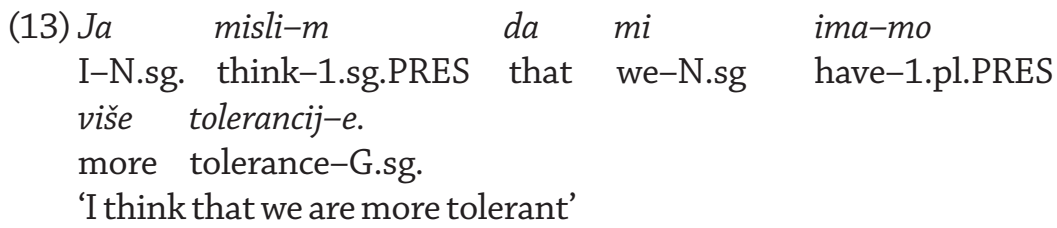

In summary, the results of our analysis confirmed that native and non-native speakers differentiate in the use of the first person personal pronouns that express W/R visibility, both quantitatively and qualitatively. The NNS use significantly more I-form pronouns than NS. Both groups use the pronoun I mostly to express three functions, two of which (writer's stance and writer's experience) are equally frequent in L1 and L2 writing, but one (stating claims) being used by NNS considerably more frequently than by NS. The following chapter moves to discuss the obtained results.

\section{Discussion}

\subsection{Use of first person personal pronouns}

This study was designed to determine whether Croatian L1 and L2 writers differ in the use of the first person personal pronouns in argumentative essays. The obtained quantitative results showed that in total, Croatian L2 writers use more first person personal pronouns than Croatian L1 writers (Table 2). The result is in line with those of previous studies on the same topic. Petch-Tyson (1998) reported that NNS of English, regardless of their L1, used more first person personal pronouns than NS to express W/R visibility. The same was confirmed by Zolotova (2014), whose results showed that, comparing to NS of English, NNS overuse all first person personal pronouns. Chang (2015) investigated only the first person personal pronoun I and came to the conclusion that Korean NNS of English have a stronger tendency to use it in argumentative essays than English NS.

The current study found that both groups of writers used the first person singular forms more frequently than the first person plural forms (Table 2). The study also confirmed that the use of $I$-forms by NNS is significantly more frequent than its use by NS (Table 3). Most of the previous studies on W/R visibility do not sup- 
port that finding. Petch-Tyson's (1998) study showed the prevalence of the plural (we forms) over the singular form (I forms) in writings by both groups of authors - NS and NNS, and her finding was supported by Zolotova (2014: 87). Vassileva (1998) explored the usage of personal pronouns in L1 texts in various languages and she reported the strongest tendency to use we forms by L1 speakers/writers in Bulgarian and Russian, and the opposite tendency in English.

There are several possible explanations of the results of the present study. To some extent the results might be related to the text genre (Bikeliene 2016; Rodríguez, Vázquez and Guzmán 2011; Zolotova 2014). Argumentative essays should present different points of view, providing the author's opinion with supporting arguments, which was clearly stated in the writing instruction. However, the participants did not receive any formal training on how to fulfill the task. Instead, they relied on their previous knowledge and writing experience. The fact that the study participants come from various educational systems, where teaching writing is approached in different ways, and from cultures / L1 with different attitudes to expressing individual vs. collective identity (Hyland 2002), might have influenced the participants. Therefore, it is not possible to explain the study results based on the characteristics of the text genre itself.

In the case of Croatian L1 writing, the dominance of I-forms over we-forms might be due to teaching of writing in Croatian L1. The authors of L1 texts were university students who are taught academic writing in Croatian. Even though academic writing is usually not a topic of a particular university course, it is implemented in university curricula. Regarding the use of verbal forms Hudeček, Frančić and Mihaljević (2006: 280) stated that in the academic writing (i.e., the scientific language style) in Croatian, the authorial we (first person plural form) is frequently used, but it can be replaced with impersonal forms or the passive. Although there are very few studies to empirically support the hypothesis, it seems that there is variety in the use of verb forms in academic writing in Croatian - from active verb forms to passive and impersonal verb forms. In other words, in order to foster objectivity in a text, Croatian L1 speakers tend to use more impersonal forms and passives and less we-forms. This hypothesis can be supported by the investigation by Bogunović and Ćoso (2013) on Croatian L1 academic writing in the field of biomedicine, who found that almost $20 \%$ of the sentences in their corpus were passive sentences. The change of trends in academic writing is a documented process. It was reported by Zolotova (2014) who claims that new pedagogical requirements and teaching materials could be the reason for Russian users of English to overuse the pronoun $I$. That allows us to assume that the same might happen in Croatian as well. However, to give a plausible explanation of Croatian NS preference to use I-forms over we-forms a larger corpus of argumentative writings should be investigated, including essays on different topics.

In the case of Croatian L2 writing, the overuse of I-forms can be caused by L1 transfer and/or it can be the result of a language learning processes. The support 
for the L1 transfer hypothesis can be found in the study by Fossan's (2011) who claims that the overuse of $I$-forms by Norwegian users of English is the result of their L1 language transfer. To test the hypothesis, she conducted a comparative analysis of Norwegian L1 and English L1 writings and confirmed the higher level of W/R visibility in Norwegian L1 writing (Fossan 2011). She suggests that high $\mathrm{W} / \mathrm{R}$ visibility in L1 (Norwegian) led to the overuse of certain language features in L2 (English) writing. The L1 transfer hypothesis would be a possible explanation of the results of the current study, especially because Croatian is a pro-drop language and the L1s of the study participants are not (English, German and French), i.e., in those languages the personal pronoun cannot be omitted. However, the L1 hypothesis cannot explain the discrepancy between the frequency of the usage of $I$-forms vs. we-forms by NNS, showed in the study. If the non-pro-drop L1 transfer was the only factor influencing the reported results, it would be visible in the usage of the $w e$-forms as well, i.e., we-forms would be used considerably more frequently in Croatian L2 writings. Considering the fact that the use of we-forms in German and French (Vassileva 1998) exceeded the use of $I$-forms, similar results would be expected in Croatian L2 writing, since half of the L2 texts in the study were written by L1 speakers of German and French. It is therefore unlikely that the NNS use of personal pronouns presented in this study is caused by L1 transfer only. However, since half of the L2 texts in this study were written by L1 speakers of L1 English, where the prevalence of the I-form was confirmed (Vassileva 1998), the L1 transfer hypothesis cannot be completely rejected.

More likely, explanation of the overuse of $I-$ forms by NNS in this study could be the process of language learning. Hasselgard (2009) and Paquot, Hasselgard and Ebeling (2013) concluded that overuse of personal pronoun I by NNS is the result of its use with mental verbs (think, believe, say, tell). Hasselgard (2009: 132) points out that "in choosing these constructions, writers thematize themselves as well as their subjective perspective on a state of affairs". She concludes (Hasselgard 2009) that the use of the lexical chain I+mental verb in L2 writing is not similar to its use in L1 written discourse, yet it is comparable to L1 spoken discourse. In other words, the L2 language use of personal pronouns could be comparable with L1 use, but in a different register, genre or style. This observation may support the hypothesis proposed by Ädel (2008), who argues for four factors to be influencing the usage of personal metadiscourse in L2 writing: genre comparability, register awareness, cultural conventions, and general learner strategies. Besides the cultural conventions, other three factors deal with learner's awareness of register features and their access to texts of different genres. More precisely, Ädel (2008: 59) concludes that "one way of explaining the differences would be to attribute them to "learner language".

\subsection{Discourse functions of first person personal pronouns}

The second research question in this study was whether Croatian L1 and L2 writers differ in the use of various discourse functions of the first person pronouns 
in argumentative essays. As mentioned in the literature review, several studies dealt with personal pronouns as a means to express W/R visibility in argumentative writing (Bagaric Medve and Saric Sokcevic 2018; Chang 2015; Fossan 2011; Petch-Tyson 1998; Zolotova 2014). It should be pointed out that these studies differ in the way in which they have classified discourse functions. For that reason, some qualitative results of this study could not be clearly interpreted with regard to previous studies. More precisely, some classifications of personal pronoun discourse functions and the results based on them do not correspond with the classification used in this study and obtained results.

The results obtained show that Croatian L2 writers use personal pronouns to express discourse functions more frequently than Croatian L1 writers (Table 5, Table 7), but the qualitative difference was only confirmed for the use of discourse function of the $I$-forms (Table 6 ). The $I$-forms were most frequently used by both groups of writers to express writer's stance and writer's experience, which confirms the findings by Zolotova (2014) and Fossan (2011). This is an expected outcome of the study, while "presenting the author's viewpoint is a key feature of argumentative writing" (Zolotova 2014: 100). Chang (2015: 96) points out that the function of opinion provider (which is an equivalent to writer's stance) accounts for $77.5 \%$ of all the usage of the pronoun I by Korean NNS of English.

The high frequency of the function writer's experience in NNS writing is contrary to that of Petch-Tyson (1998) and Zoltova (2014). Both authors argued for the discourse function writer's experience to be typical for NS. Petch-Tyson (1998) claims that expression of personal experience present in NNS writing varies depending on writers' L1, i.e., it was found only in the writing of Finish and Swedish learners of English, but not in French and Dutch (Petch-Tyson 1998: 111). Moreover, Zolotova (2014: 101) points out that "learners underuse the function, and the underuse is statistically significant". Even though, the reason for high frequency of this function cannot be established in this study, it seems possible that these results are due to the language learning process. Chang (2016:107) claims that advanced students prefer to use $I$ to assert their writer stance, while students at lower proficiency levels chose I to "describe the writer's personal experience, state of mind, or expectations". Since the participants of the study were at the intermediate level (B1 at least), their preference to use pronoun I to express writer stance might indicate their language advancement. On the other hand, as stated in the previous section, the conducted study showed (at least) two subtypes of examples that refer to the writers' experience: experience based on a specific event (4a) and experience that arises as the result of multiple events in a writer's life (4b). This fact, together with the contradictory results of Petch-Tyson (1998) and Zoltova (2014), suggest that introducing two sub-categories of the function referring to the writer's experience might result in a clearer picture of discourse functions of the $I$-forms.

Another important finding of the study was the high frequency of the discourse function stating claims by NNS (Table 6). Due to different classifications of 
discourse functions in other studies, the frequency of the function stating claims can be compared only to findings by Bagaric Medve and Saric Sokcevic (2018). In their study on writings of Croatian speakers in their L2, the frequency of the function was in the lower range, which is in line with the use of the same function by NS in this study. Since Bagaric Medve and Saric Sokcevic (2018) confirmed low frequency of the function stating claims in Croatian learners of English/German, and this study confirms the same low frequency in Croatian L1 writings (Table 6), it seems possible that the use of the function stating claims is culturally or linguisticallybound.

One unanticipated finding of this study was a relatively low frequency of the functions elaborating an argument and indicating discourse structure (Table 6) by both groups of writers. In the NS essays the function indicating discourse structure was the least frequent function (together with stating claim), whereas the function of elaborating an argument was not expressed in the essays. The result of the use of the pronoun I to structure the discourse by NS is in line with the findings by Zolotova (2014) and Fossan (2011). In Russian L1 (Zolotova 2014: 100) the function was not expressed, and in English L1 writings it had relatively low frequency (Fossan 2011; Zolotova 2014). On the other hand, the frequency by NNS was much higher (Bagaric Medve and Saric Sokcevic 2018; Fossan 2011; Zolotova 2014). It is possible that the result is due to the language learning process. Namely, Fossan (2011: 130) argues that language learners show "the need to guide the reader through the text", especially in a short text.

The personal pronoun for the first person plural (we) was used only for expressing two functions: presenting a general claim and establishing solidarity, by both groups of writers. Since the NNS produced more personal pronouns that NS, it was expected that the frequencies of both functions would be higher by NNS (Table 7). The findings of the use of both functions of the pronoun we are in line with Zolotova (2014) and Fossan (2014). Zolotova (2014) argues that the most frequent functions of the pronoun we correlate with the most frequent functions of the pronoun I. This is an argument confirmed by this study as well. Namely, the NS and NNS used the first person personal pronouns to express their opinion, as more personal (I-forms) or more general (we-forms). Since the quantitative results did not show a significant difference in the NS's vs. NNS's use of we-forms, it can be suggested that Croatian L2 writing in the use of we-forms is more like Croatian L1 writing, i.e., the language learners have acquired the notion of the target language.

\section{Conclusion}

The aim of this paper was to investigate the pragmatic notion of writer/reader visibility in Croatian L1 and L2 writing. Specifically, we focused on the use of first person personal pronouns by native and non-native speakers. The conducted study confirmed the differences between the groups. NNS use I-form and we- 
forms more frequently than NS. However, only the overuse of $I$-forms is proven to be statistically significant. The frequency of the use of I pronoun over we pronoun by NS is contrary to previous studies, especially those of NS of Slavic languages.

According to the data, we can infer that cultural and language-specific factors are of great importance to the use of personal pronouns to express W/R visibility in L1. On the other hand, a strong tendency of Croatian NNS to use I-forms is in line with previous studies, which might support the hypothesis of the universal nature of the second/foreign language learning process. The qualitative analysis provides evidence that in argumentative essays in Croatian, the pronoun $I$ is used mostly to express writer's stance and the writer's experience, whereas the pronoun we is used for the same purpose (presenting a general claim), thus to a much lower frequency. However, the specificities of learners' (inter)language are observed in the use of pronoun I for stating claims. Its considerably higher frequency by NNS than NS might be due to L1 transfer or the language learning process. The relatively small corpus and its limitation to one topic and one essay per participant, make us to interpret the results with caution.

Notwithstanding these limitations, the findings reported in this paper shed new light of the use of personal pronouns in Croatian L1 and L2 argumentative writing. More general, the study contributes to our understanding of writing skills being influenced by cultural, linguistic, and, in this case, language learning factors. Further studies need to be carried out to explore the use of other personal pronouns and their discourse function in Croatian, to improve our knowledge of writing skills not only in Croatian, but in a first and a second/foreign language in general.

\section{Literature}

Ädel, Annelie (2001). On the search for metadiscourse units. Rayson, Paul, Andrew Wilson, Tony McEnery, Andrew Hardie, and Shereen Khoja, ed. Proceedings of the Corpus Linguistics 2001 conference: UCREL Technical Papers, Volume 13, Special Issue. Lancaster: Department of Linguistics. Lancaster University, 3-13

Ädel, Annelie (2008). Metadiscourse across three varieties of English: American, British, and advanced-learner English. Connor, Ulla, Ed Nagelhout, and William V. Rozycki, ed. Contrastive Rhetoric. Reaching to intercultural rhetoric. Amsterdam/Philadelphia: John Benjamins Publishing Company, 45-63

Ball, Arnetha F., and Pamela Ellis (2009). Identity and the Writing of Culturally and Linguistically Diverse Students. Bazerman, Charlie, (ed). Handbook of Research on Writing. History, Society, School, Individual, Text. New York, London: Lawrence Erlbaum Associates, Taylor and Francis Group, 614-633

Bagaric Medve, Vesna, and Saric Sokcevic, Ivana (2018). Discourse Functions of Personal Pronouns in EFL Learners' Argumentative Texts. Literacy skills in educational environments: changing theories and practices. Bialska Podala, presentation.

Bazerman, Charles (ed.) (2009). Handbook of Research on Writing. History, Society, School, Individual, Text. New York, London: Lawrence Erlbaum Associates, Taylor and Francis Group 
Bestgen, Yves, and Sylviane Granger (2014). Qualifying the development of phraseological competence in L2 English writing: an automated approach. Journal of Second Language Writing 26: 28-41

Bikeliené, Lina (2016). Person markers in non-native students' writing. Verbum 7: 34-43, https://doi.org/10.15388/Verb.2016.7.10284

Byrnes, Heidi, and Rosa M. Manchón (ed.) (2014). Task-based language learning - Insights from and for L2 Writing. Amsterdam/Philadelphia: John Benjamins Publishing Company

Bogunović, Irena, and Bojana Ćoso (2013). Engleski u hrvatskome: znanstveni izričaj biomedicine i zdravstva. Fluminensia 25(2): 177-191

Breeze, Ruth (2007). How Personal is this Text? Researching Writer and Reader Presence in Student Writing Using Wordsmith Tools. CORELL: Computer Resources for Language Learning 1: 14-21

Chang, Yi-Jeon (2015). A Comparison of the First-Person Pronoun I in NS and Korean NNS Corpora of Argumentative English Writing. English Teaching 70(2): 83-106

Chang, Yin-ling (2016). Personal Pronouns in Argumentative Essays: Discourse Functions and Patterns of Use. Journal of English Education 3(1): 93-129

Didriksen, Andre A., and Anje Muller Gjesdal (2006). Genre constraints and individual linguistic variation. Suomela-Salmi, Eija, and Fred Dervin, eds. Perspectives inter-culturelles et inter-linguistiques sur le discours académique. Turku: Université de Turku, 47-57

Dyson, Anne Haas (2000). On refraining children's words: The perils, promises, and pleasures of writing children. Research in the Teaching of English 34(3): 352-367

Fløttum, Kjersti, Trine Dahl, and Torodd Kinn (2006). Academic Voices: Across Languages and Disciplines. Amsterdam/Philadelphia: John Benjamins Publishing

Fossan, Heidi (2011). The Writer and the Reader in Norwegian Advanced Learners' Written English. Oslo: University of Oslo

Gee, James Paul (2003). A sociocultural perspective on early literacy development. Neuman, Susan B., and David Dickinson, eds. Handbook of early literacy research. New York: Guilford, 30-42

Grabe, William, and Robert B. Kaplan (1996). Theory and practice of writing: An applied linguistic perspective. London: Longman

Hudeček, Lana, Milica Mihaljević, and Anđela Frančić (2006). Normativnost i višefunkcionalnost u hrvatskome standardnom jeziku. Zagreb: Hrvatska sveučilišna naklada

Hyland, Ken (2002). Authority and invisibility: authorial identity in academic writing. Journal of Pragmatics 34: 1091-1112, https://doi.org/10.1016/S0378-2166(02)00035-8

Hasselgard, Hilde (2009). Thematic choice and expressions of stance in English argumentative texts by Norwegian learners. Aijmer, Karin, ed. Corpora and Language Teaching. John Benjamins Publishing Company, 121-141

Keller, Stefan D., Johanna Fleckenstein, Maleika Krüger, Olaf Köller, and André A. Rupp (2020). English writing skills of students in upper secondary education: Results from an empirical study in Switzerland and Germany. Journal of Second Language Writing, https://doi.org/10.1016/j.jslw.2019.100700 
Kubota, Ryuko, and Al Lehner (2004). Toward critical contrastive rhetoric. Journal of Second Language Writing 13 (1): 7-27, https://doi.org/10.1016/j.jslw.2004.04.003

Luan, Junhan, and Yi Zhang (2016). A Comparative Study of the Use of First Person Subject Pronouns in Chinese and Swedish Students' Argumentative Essays. A Corpus-based Research. International Journal of Education and Research 4(11): 341-352

Manchón, Rosa M. (ed.) (2011). Learning-to-Write and Writing-to-Learn in an Additional Language. Amsterdam/Philadelphia: John Benjamins Publishing Company

Marković, Ivan (2012). Uvod u jezičnu morfologiju. [Introduction to Linguistic Morphology] Zagreb: Disput

McCrostie, James (2008). Writer visibility in EFLlearner academic writing: A corpus-based study. ICAME Journal 32: 97-114

Michel, Marije, Judit Kormos, Tineke Brunfaut, and Michael Ratajczak (2019). The role of working memory in young second language learners' written performances. Journal of Second Language Writing 45: 31-45, https://doi.org/10.1016/j.jslw.2019.03.002

Paquot, Magali, Hilede Hasselgård, and Singe Oksefell Ebeling (2013). Writer/reader visibility in learner writing across genres. A comparison of the French and Norwegian components of the ICLE and VESPA learner corpora. Granger, Sylviane, Gaëtanelle Gilquin, and Fanny Meunier, eds. Twenty Years of Learner Corpus Research:Looking back, Moving ahead. Corpora and Language in Use - Proceedings 1. Presses Universitaires de Louvain, 377-387

Petch-Tyson, Stephanie (1998). Writer/reader visibility in EFL Writen Discourse. Granger, Sylviane, ed. Learner English on Computer. Longman: London and New York, 107-118

Roux Rodriguez, Ruth, Alberto Mora Vazquez, and Nelly Paulina Trejo Guzman (2011). Exploring Writer Identity in Mexican EFL Students' Academic writing. Íkala, Revista de Lenguaje y Cultura 16(28): 93-115

Tayyebi, Masoumeh (2012). Personal pronouns in English and Persian medical research articles. English for Specific Purposes World 36(12)

Vassileva, Irena (1998). Who am I/who are we in academic writing?. International Journal of Applied Linguistics 8(2): 163-190, https://doi.org/10.1111/j.1473-4192.1998.tb00128.x

Wang, Yingli (2012). Differences in L1 and L2 Academic Writing. Theory and Practice in Language Studies 2(3): 637-641, https://doi.org/10.4304/tpls.2.3.637-641

Wells Rowe, Deborah (2009). Development of Writing Abilities in Childhood. Bazerman, Charles, ed. Handbook of Research on Writing. History, Society, School, Individual, Text. New York, London: Lawrence Erlbaum Associates, Taylor and Francis Group, 491-516

Whitmore, Kathryn F., Prisca Martens, Yetta M. Goodman, and Gretchen Owocki (2004). Critical lessons from the transactional perspective on early literacy research. Journal of Early Childhood Literacy 4(3): 291-325

Zolotova, Ekaterina (2014). Who am I? and Who are we? in argumentative and academic writing. A corpus-based study of author identity in the writing of native speakers and Russian learner of English. MA thesis, Oslo: University of Oslo 


\section{Vidljivost autora u argumentacijskim esejima u J1 i J2: uporaba osobne zamjenice za prvo lice u hrvatskom jeziku}

Razvoj jezične djelatnosti pisanja obuhvaća ovladavanje jezičnim obilježjima, funkcionalnim stilovima i registrima povezanim uz pojedine tekstne vrste i žanrove, kao i učenje o tome kako pisanjem izraziti sebe. Uključenost autora u tekst ili vidljivost autora, obilježava uporaba ličnih zamjenica za prvo i drugo lice, prikazivanje autorovih umnih procesa, uporaba osjećajnih čestica i druge značajke (Petch-Tyson 1998). Dosadašnja su istraživanja pokazala da način iskazivanja vidljivosti autora ovisi o čimbenicima poput vrste teksta, kulturoloških konvencija, stupnja ovladanosti jezikom, autorova prvoga jezika itd. (Ädel 2001; Petch-Tyson 1998; Rodríguez, Vázquez and Guzmán 2011; Zolotova 2014). U ovome se radu istražuje iskazivanje autorove vidljivosti u tekstovima na hrvatskome kao materinskome (J1) i inome (J2) jeziku. U istraživanju se polazi od pitanja o tome razlikuju li se izvornojezični i inojezični govornici hrvatskoga jezika u uporabi osobnih zamjenica za prvo lice jednine i množine pri pisanju argumentacijskih tekstova. Građu za analizu činilo je 80 argumentacijskih eseja izvornih $(\mathrm{N}=40)$ i inojezičnih govornika $(\mathrm{N}=40)$ hrvatskoga jezika, a na temelju prikupljenegrađe provedenajekvantitativnai kvalitativna analiza. Kvantitativna analiza pokazala je da inojezični govornici hrvatskoga jezika češće od izvornojezičnih rabe osobne zamjenice za prvo lice. No, statistički značajna razlika pokazala se samo za uporabu zamjenice ja (u svim padežima), dok za uporabu zamjenice mi nije bilo statistički značajne razlike između dvije skupine govornika. Kvalitativna analiza pokazala je da obje skupine zamjenicu ja najčešće rabe u diskursnim funkcijama izražavanja autorova stava i autorova iskustva, a zamjenica mi također se najčešće rabi za izricanje slične funkcije (iskazivanje opće tvrdnje). Kvantitativni rezultati djelomično potvrđuju nalaze za druge jezike, a dijelom ukazuju na specifičnosti hrvatskoga jezika. $S$ druge strane, kvalitativni rezultati uz visok stupanj sličnosti u uporabi zamjenica za iskazivanje diskursnih funkcija u prvome i inome jeziku također pokazuju i neke specifičnosti uporabe ličnih zamjenica kod neizvornih govornika. Dobiveni rezultati donijeli su nove spoznaje o pisanju na hrvatskome kao materinskome i inom jeziku te su na široj razini kao bitne čimbenike na ovladavanje pisanjem u inome jeziku potvrdili kulturološke i jezične značajke te proces ovladavanja inim jezikom.

Keywords: writing, writer visibility, personal pronouns, Croatian as L1 and L2

Ključne riječi: pisanje, vidljivost autora, lične zamjenice, hrvatski jezik, ini jezik 